\title{
LXXI. On the immersion of copper for bolts and shipsheathing in muriatic acid, as a test of its durability
}

\section{David Mushet Esq.}

To cite this article: David Mushet Esq. (1835) LXXI. On the immersion of copper for bolts and shipsheathing in muriatic acid, as a test of its durability , Philosophical Magazine Series 3, 6:36, 444-447, DOI: $10.1080 / 14786443508648641$

To link to this article: http://dx.doi.org/10.1080/14786443508648641

曲 Published online: 01 Jun 2009.

Submit your article to this journal $[\pi$

ЏII Article views: 3

Q View related articles $\sqsubset$ 
The following table would at first give additional facility in changing the decimal scale into the present, and vice versâ.

\begin{tabular}{|c|c|c|}
\hline$d$ & & $\begin{array}{l}\text { imal Values of the } \\
\text { Half-Pound. }\end{array}$ \\
\hline 4 & $=$ & .0020 \\
\hline & $=$ & $\cdot 0041$ \\
\hline 4 & $=$ & •0062 \\
\hline 1 & $=$ & .0083 \\
\hline $1 \frac{1}{4}$ & $=$ & .0104 \\
\hline $1 \frac{1}{2}$ & $=$ & .0125 \\
\hline $1 \frac{3}{4}$ & $=$ & $=0145$ \\
\hline $2^{4}$ & $=$ & .0166 \\
\hline $2 \frac{1}{4}$ & $=$ & 0187 \\
\hline $2 \frac{1}{2}$ & $=$ & $\cdot 0208$ \\
\hline $2 \frac{3}{4}$ & $=$ & .0229 \\
\hline $3^{x}$ & $=$ & $\cdot 0250$ \\
\hline
\end{tabular}

\begin{tabular}{|c|c|c|}
\hline$d$ & \multicolumn{2}{|c|}{$\begin{array}{l}\text { Decimal Values of the } \\
\text { Hall-Pound. }\end{array}$} \\
\hline $3 \frac{1}{4}$ & $=$ & \\
\hline $3 \frac{1}{2}$ & $=$ & .0291 \\
\hline $3 \frac{3}{4}$ & $=$ & 0312 \\
\hline 4 & $=$ & $\cdot 0333$ \\
\hline $4 \frac{1}{4}$ & $=$ & $\cdot 0354$ \\
\hline 7 & $=$ & $\cdot 0375$ \\
\hline $4 \frac{3}{4}$ & $=$ & .0395 \\
\hline 5 & $=$ & $\cdot 0416$ \\
\hline $5 \frac{1}{4}$ & $=$ & $\cdot 0437$ \\
\hline $5 \frac{1}{2}$ & $=$ & $\cdot 04.58$ \\
\hline $5 \frac{3}{4}$ & $=$ & $\cdot 04.79$ \\
\hline 6 & $=$ & $\cdot 0500$ \\
\hline
\end{tabular}

Being desirous of giving publicity to the results of $\mathrm{my}$ inquiries on this subject, I have put them into the present form, in the hope that you will be able to find for them a spare page or two of your valuable scientific periodical.

His Majesty's Dockyard,

I beg to remain, Gentlemen, Your obedient Servant, Chatham, Feb. 4th, 1835.

Samuel Read.

LXXI. On the Immersion of Copper for Bolts and Shipsheathing in Muriatic Acid, as a Test of its Durability. By David Mushet, Esq.

THE durability of copper for bolts and ship-sheathing being an object of great national importance, and as there is no better test of its resistance to waste than immersion in muriatic acid, the following experiments, made thirteen years ago, will, it is hoped, be found not uninteresting.

Small quantities, presenting nearly equal surfaces of each of the kinds of copper described in my last communication, p. 324, namely, pure shotted copper of the quality from which brass is made, and shots obtained from unrefined copper, were separately immersed in equal weights of muriatic acid. The immersion having been continued for forty-eight hours, the acid was poured off, and the copper washed repeatedly and

cimal money table for the term " half-pound ;" our accounts being kept in regents, shillings, tenths, and cents, instead of half-pounds, shillings, tenths, and cents. For this suggestion I an indebted to a friend well known in scientific circles, and to whom I have communicated the subject-matter of this paper.-March $11 t h, 1835$. S. R. 
thoroughly dried. The pure copper had lost at the rate of $5 \frac{1}{2}$ grains in 100. But the unrefined copper, on being weighed, seemed to have gained half a grain; so that either a mistake must have been made in the weighing, or else a portion of unexpelled moisture had remained in the porous flakes of the copper.

Six ounces of unrefined copper were mixed with three times their bulk of charcoal, and exposed for six hours to a high heat of cementation, much beyond what in the absence of the cementation would have sufficed to melt the copper. The flakes of copper were found surrounded by the charcoal, welded together without fusion, and soft and extremely flexible. Six ounces of the pure copper shots were treated in a similar manner; but the result was so far different that no adhesion of the masses had taken place, and the only perceptible change was a slight cracking or bursting upon the surface of the spheroids, which may be considered as a prelude to fusion. Both results were melted down with charcoal and run into iron moulds. The unrefined copper, when cold, was the strongest and softest; a bar of it, about $\frac{3}{8}$ ths of an inch thick, cut easily across with a knife, and in colour and general appearance it very nearly resembled Swedish copper. Another piece was flattened out thin when cold for the purpose of immersion in the muriatic acid. The pure copper was melted in rather a higher degree of heat, and although not teemed until it had assumed a creamy surface, and the crucible had fallen to a low red temperature, it was crystallized through.out the whole fracture. The surface and the fracture of this copper were of a red colour; the body weak, and tearing with facility into pieces. Fragments for immersion were cut off and flattened.

The following specimens were then placed separately in muriatic acid.

No. 1. Pure copper, cut off with a chisel, $\ldots 53$ grains.

2. Ditto, flattened, ... 30 -

3. Unrefined copper, cut off with a knife, $39 \frac{1}{2}-$

4. Ditto, flattened, in which stuck a $\} 42-$

On the morning of the third day the following remarks were made upon their respective solutions.

No. 1, Light green colour, very transparent when dashed against the sides of the glass. No. 2, Equally transparent, but the green was brownish and not so decidedly cupreous. After continuing the immersion for 48 hours longer, the acid was poured off and the specimens were well washed and dried. 
No. 1, That weighed 53 grains, now weighed ... $39 \frac{1}{2}$ grains. Loss $13 \frac{1}{2}$ grains. Equal to $25^{\circ} 4$ per cent.

No. 2, That weighed 30 grains, now weighed ... $11 \frac{1}{2}-$ Loss $18 \frac{1}{2}$ grains. Equal to $61 \cdot 6$ per cent.

$\left.\begin{array}{c}\text { No. 3. Unrefined copper flattened, } 39 \frac{1}{2} \text { grs., } \\ \text { now weighed }\end{array}\right\} 19-$

Loss $20 \frac{1}{2}$ grains. Equal to 50 per cent.

No. 4. Unrefined copper bar, 4.2 grs., now weighed $38 \frac{1}{2}-$ Loss $3 \frac{1}{2}$ grains. Equal to $8 \frac{33}{100}$ percent.

It would appear from this experiment that the unrefined copper resists waste in the muriatic acid, in the same way, and to nearly the same extent, as in the cementation with lime mentioned in my last previous paper, p. 325 .

In corroboration of this fact, we may take the following abstract of another series of experiments, wherein the specimens were weighed three times, at intervals of 48 hours between each weighing.

Unrefined copper, 1st immersion, lost... 15 per cent.

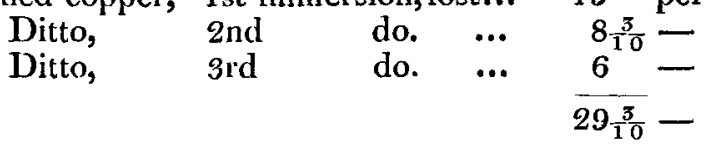

\begin{tabular}{rlllrl} 
Pure copper, & \multicolumn{2}{c}{ 1st immersion } & $\ldots$ & $25 \cdot 4$ & - \\
Ditto, & 2nd & do. & $\ldots$ & $9 \cdot 7$ & - \\
Ditto, & 3rd & do. & $\ldots$ & $11 \cdot 1$ & - \\
& & & & $\frac{46 \cdot 2}{2}$ & -
\end{tabular}

In favour of the unrefined copper, principally containing tin,-16.9 per cent. Two pieces of copper, the one pure the other unrefined, were immersed, under similar circumstances, for seven days. The unrefined copper lost 17 per cent. and the pure copper 45 per cent. To ascertain whether the greater indestructibility was owing to the tin which remained in the unrefined copper, I formed a bar of alloy as follows :

$$
\begin{array}{llr}
\text { Pure copper } & \ldots & 2880 \text { grains. } \\
\text { Block tin } & \ldots & 84
\end{array}
$$

A proportion of tin about equal to 3 per cent. A piece from this bar, weighing about 183 grains, was exposed for seven days in muriatic acid, at the end of which time it was found to have lost 30 grains, or $16 \frac{4}{10}$ per cent. The unrefined copper above mentioned lost, in the same time and under similar circumstances, 17 per cent., which is a striking correspondence. The same piece of tin alloy, at the end of five weeks, was found to have lost in all 76 grains, or $38 \frac{1}{2}$ per cent. Pure 
copper by the foregoing results lost in seven days' immersion 46.2 and 4.5 per cent.

In the first instance I was inclined to attribute the indestructibility of the unrefined copper in the acid partly to the effects of the charcoal in the cementation, seeing that the effect produced by that operation was much greater upon unrefined than upon pure copper. Whatever advantages may belong to the proper use of charcoal in the reduction and cementation of copper, (and I consider them not unimportant,) the addition of a small portion of tin will be sufficient to account for the superior resistance to waste which this alloy presents in the muriatic acid, over that of the common refined copper of this country. This incapacity to rapid oxidation which is presented by the alloy of tin with copper, suggests many useful hints to the artist and the manufacturer, of which advantage has already been taken in forming ship-sheathing and other articles.

David Mushet.

LXXII. Insectorum nonnullorum exoticorum (ex Ordine Dipterorum) Descriptiones. Auctore J.O.Westwood, F.L.S.\&.c. [Continued from p. 281.]

DHILOPOTA, Wied. Maculicollis, Westw. Nigra; thorace anticè maculis 2 minutissimis, alterisque 2 parvis ad basin alarum fulvis; abdominis marginibus tenuitèr flavo notatis, segmentis terminalibus, sericie subaureâ tectis; antennis nigris ; facie albidâ; femoribus nigris, apice rufis, pedum geniculis pallidis; alis infumatis.-Long. corp. lin. $4 \frac{1}{2}$. Exp. alar. lin. $11 \frac{1}{2}$.

Habitat in Brasiliâ. "Capta D. Swainson." In nus. nostr.

Lepidophona, Westw. (Fam. Bombyliide.)

Antennæ capite triplò longiores, squamulis obtectæ, articulo Imo? brevi, 2ndo longo gracili, 3tio breviori latiori, stylo apicali. Proboscis antennarum dimidiò brevior. Thorax valdè gibbosus. Abdomen elongatum, parallelum, caudâ squamulosâ ornatum. Alæ farinosæ, nervis ut in Cylleniấ dispositis. Pedes longi, graciles.

Obs. Cel. Kirby et Spence hoc genus commemorant libro "Introd. to Ent." vol. iii. p. 646, pl. 12, f. 23, ubi Culicem cum Anthrace, \&c., conjungere credunt.

Sp. 1. Lep. ageriiformis, Westw. MSS. Ploas ageriiformis, G. R. Gray, in Griff. An. K. pl. 128.

Niger; thoracis lateribus flavo pubescentibus; abdomine maculis 6 latera-

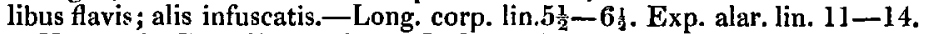

Habitat in Georgiâ Americæ.- In Muss. Brit. et nostr.

Obs. Toxophora lepidocera Wied. congenerica videtur.

Nemestrina, Latr. Rhynchocephalus, Fisch. Fallenia, Meig. t. 2.

Subg. 1. Fallenia, Macq. Palpi elongati, attenuati; antennarum stylo 